\title{
EFFICIENCY OF ACETIC ACID AND METHOMYL ON TERRESTRIAL SNAILS EOBANIA VERMICULATA (MÜLLER ) AND MONACHA OBSTRUCTA (FEROSSAC ) UNDER LABORATORYAND FIELD CONDITION.
}

\author{
Eman Kamel Khidr \\ Plant Protection Research Institute, Agricultural Research Center, Dokki, Egypt. \\ Corresponding author: dremankamel@yahoo.com
}

\begin{abstract}
Some laboratory experiments and field trials were conducted to study the effiecieney of acetic acid and the molluscicides methomyl against theterrestrial snails, Eobania. Vermiculata Müler and Monacha. obstructa Ferrosac were investigated under laboratory and field conditions. The results showed that, acetic acid had a highly significant effect on Monacha. obstructa than Eobania. vermiculata, whereas, the mortality percent was higher for M. obstructa $(100 \%)$ at the concentration of $10 \%$ after 72 hrs. than E. vermiculata, which recorded $(50 \%)$ mortality at the same concentration and the same time. The $\mathrm{LC}_{50}$ values recorded, 8.69 and $2.19 \%$ after $72 \mathrm{hrs}$ of application for $E$. vermiculata and $M$. obstructa respectively. The effect of the applied compound (acetic acid) on certain biochemical parameters were recognized at the $\mathrm{LC}_{50}$ level, the total protein activities showed increasing for both snails species when compared with control. The same compound showed decrease in the level of total lipid from 4.96 to 2.78 for $E$. vermiculata while total lipid increased from 2.89 to $3.22 \mathrm{~g} / \mathrm{dl}$ for M. obstructa respectively. Also decrease in the level of alkaline and acid phosphatase in both land snail species were recorded at Lc 50 level .On the other hand, the results cleared that acetic acid achieved the decreased effect on the cholesterol for E. vermiculata while it increased the cholesterol for M. obstructa. On the other side, the obtained data of the field trials which carried out at Qalubyia Governorate Toukh district (shubra harris) in citrus orchards using acetic acid and methomyl proved that $M$. obstructa had more sensitivity to the tested compound than E. vermiculata.
\end{abstract}

Keywords: Acetic acid, Methomyl Eobania, vermiculata Müler, monacha obstructa ferrosac , Snails.

\section{INTRODUCTION}

The terrestrial molluscs are considered a major pest of a wide range of agricultural crops in temperate and humid habitats worldwide (Speiser and Kistler [20]. They attack plants causing great damage to the cultivated plants. Economic damage caused by these molluscs is due to feeding and to contamination with their bodies, feces or slime leading to deterioration of the product quality, in addition the financial loss Iglesias et al., [11]. In Egypt terrestrial snails attack vegetables, field crops, orchard trees as well as ornamental and medical plants. Monacha obstructa (Ferussac) and Eobania vermiculata (Müler) are the important snail species in the Egyptian Governorates attacking various plantations Eshra [7], Khidr,E.k. [14]. Azzam and Abd El-Hady [3], recorded seven snail species and three slug species infesting about 47 species of plants in seven Governorates in Egypt including Cairo and Arish. Shell is very important for protecting snail from any risk. Therefore the main aim of this work is shedding some light on the efficiency of acetic acid on E. vermiculata and $M$. obstructa under laboratory and field conditions. Also its effect on some biochemical parameters affecting the synthesis of shell such as alkaline and acid phosphatase, total protein, total lipid and cholesterol contents had investigated.

\section{MATERIALS AND METHODS}

Tested Compounds . a-Common name: Acetic Acid 96\% $\mathrm{CH}_{3} \mathrm{COOH}$<smiles>CC(=O)O</smiles>

\section{b- Common name: methomyl (90\%)}

Trade name: Newmyl (90\% SP) Is a Carbamate compound.

Iupac Name S-methyl $\mathrm{N}$-(methylcarbamoyloxy) thioacetimidate. Chemical name:methyl N- [[ (methyl amino)carbonyl] oxy] thioacetimidate. It was obtained from Kafr El-Zayat Company, Egypt. The Egyptian 
Ministry of Agriculture and Land Reclamation (MALR) recommends this compound for use against land snail infestation in Egyptian fields, (Molluscicide)

Action: Insecticide.<smiles>CNC(=O)ON=C(C)C</smiles>

\section{Experimental Animals}

Adult individuals of the two terrestrial snail species, E. vermiculata and M. obstructa were collected from the infested fields cultivated with Egyptian clover and ornamental plants at Qalubyia Governorate. Animals were transferred to laboratory, kept in glass boxes and fed on fresh lettuce leaves. For each treatment, 40 healthy animals were allocated and divided into four replicates (each of 10 individuals) and another for control.

\section{Laboratory Contact Application}

Animals were treated with different concentrations of the tested compound using thin layer film technique according to the method of Ascher and Mirian [2]. Two $\mathrm{ml}$ of the tested concentration of the tested compound were spread on inner surface of a Petri- dish using water moving the dish gently in circles. Water was evaporated under room conditions in a few minutes leaving a thin layer film of the tested compounds. Animals were exposed to different concentrations of tested compound for one week. A parallel control test was conducted using plain water. Mortality percentages were recorded and corrected according to Abbott's formula [1].

$$
\text { corrected } \%=1-\frac{\text { No,of snails in treatment after treatment }}{\text { No of snails in control after treatment }} \times 100
$$

\section{Field Experiments:}

Two compounds, acetic acid and methomyl (recommended compound) were tested against the two land snail species under field conditions. The performance of the tested compounds was studied under field conditions at Qalubyia Governorate Toukh district (shubra harris) on plantation of citrus nursery trees for E. vermiculata and $M$. obstructa. Four plots (each of $4 \mathrm{~m}^{2}$ ) were chosen. Two plots were used for acetic acid, the third for methomyl and the four was left without treatment as control. Each plot was far from the other by at least $4 \mathrm{~m}$. The tested compounds were applied as a spray the snails infested plants were counted daily pre and post treatment during 15 days. The efficiency of compounds was based on the reduction of snails population after 15 days of treatment according to the formula of Henderson and Tilton [9] as follows :

Reduction percentage $=1-\frac{\left(\mathrm{C}_{1} \times \mathrm{T}_{2}\right)}{\left(\mathrm{C}_{2} \times \mathrm{T}_{1}\right)} \times 100$

$\mathbf{C}_{1}=$ population of snails in control before application,

$\mathbf{C}_{2}=$ population of snails in control after application,

$\mathbf{T}_{1}=$ population of snails in treatment before application,

$\mathbf{T}_{2}=$ population of snails in treatment after application,

\section{Biochemical Parameter Determination:}

The activities of some enzymes and biochemical parameters were studied to clarify the physiological response of the terrestrial snail to the tested compounds i.e., alkaline and acid phosphatase, total protein, total lipid and cholesterol contents. The parameters were determined after 3 days of treatment. Samples were prepared according to the method of Bergmeyer [5] .

4.1. Alkaline and acid Phosphatase (ALP and $\mathrm{ACP}$ ): Both alkaline and acid phosphatase activity was determined according to method of Kind and King [15] and Belfield and Goldberg [4] .

4.2. Total Protein: Soluble protein was determined using the method of Henry [10] and Tietz [21].

4.3. Total lipid: Lipids are hydrolyzed by sulphoric acid, then treated with phosphovanilin mixture to produce sulphophosphovanilin complex of rose coloration which is measured photometrically according to Zollner and Kirsch [23].

4.4. Cholesterol: Cholesterol concentration was determined according to method of Ellefson and Caraway [6].

\section{Statistical analysis:}


The data was subjected to analysis of variance (ANOVA) and the means were compared by L.S.D test at 0.05 levels, using SAS program (SAS Institute,)[19].

\section{RESULTS AND DISCUSSION}

The gained results in table (1) and Fig.(1a\&b) showed the effect of acetic acid on the adult age of the two snails species. The data revealed that, acetic acid caused $0.0,25$, $35,40,50,65$ and $75 \%$ mortality for $E$. vermiculata after 3 day of treatment when using concentrations of $2,4,6,8,10,12$ and $14 \%$ respectively meanwhile for $M$. obstructa the concentrations $2,4,6,8$ and $10 \%$ caused mortality 40, 90, 92.5, 100 and $100 \%$ respectively comparing with the untreated control. The $\mathrm{LC}_{50}$ values recorded, 8.69 and $2.19 \%$ after $72 \mathrm{hr}$. of application for $E$. vermiculata and $M$. obstructa respectively. Mobarak [16] reported that $\mathrm{LC}_{50}$ of abamectin biocide against the two snail species $E$. vermiculata and $M$. obstructa were 30.9 and $877.0 \mathrm{ppm}$ consecutively. She also recorded that acetylsalicylic acid when used against the same two snail species had more effect against M. obstructa as its $\mathrm{LC}_{50}$ and $\mathrm{LC}_{90}$ reported 1354.6 and $38873.7 \mathrm{ppm}$ than $E$. vermiculata since $\mathrm{LC}_{50}$ and $\mathrm{LC}_{90}$ were 14975.9 and $1156600 \mathrm{ppm}$ respectively. Youssef [22] reported that abamectin was the most effective compound against $E$. vermiculata and $M$. contiana, where it achieved 90 and 100\% mortality for two species, respectively.

Biochemical impacts of acetic acid on $E$. vermiculata and M. obstructa:

\section{a. Total protein:}

The response of total protein to the treatment as a contact against both snail species was shown in Table (2) .The results showed significant increase in total protein from 0.195 to $1.99 \mathrm{~g} / \mathrm{dL}$ for $E$. vermiculata and from 0,168 to $2.10 \mathrm{~g} / \mathrm{dL}$ for $M$. obstructa after 3 days of treatment with the tested compound.

Khater et al. [13] reported that the increase in total protein could be attributed to the increased biosynthesis process occurred by high enzyme stress.

\section{b. Total Lipid:}

The obtained results in table (2) showed also a different effect of the acetic acid on the total lipid on both snail species. whereas a decreased in the level of total lipid from 4.96 to $2.78 \mathrm{~g} / \mathrm{dL}$ for $E$. vermiculata were recorded .In contrast the total lipid increased from 2.89 to $3.22 \mathrm{~g} / \mathrm{dL}$ for $M$. obstructa after the 3 days of treatment.

Mobarak,. [14] reported that the acetylsalicylic acid affected on the total lipid and cholesterol which important for synthesis of shell. ) Observed that acetylsalicylic acid when combined with methomyl was more effective against both alkaline and acid phosphatase enzymes than each compound alone in the two snail species, E. vermiculata and M.obstructa

\section{c. Alkaline and acid phosphatase:}

Data in the same table illustrated the effect of acetic acid on alkaline and acidic phosphatase in both land snails species after 3 days of treatment. Results revealed that acetic acid resulted in decreasing in the level of alkaline phosphatase from 666.58 to $86.9 \mathrm{U} / \mathrm{L}$ for E. vermiculata and from 333.92 to 212.41 $\mathrm{U} / \mathrm{L}$ for $M$. obstructa. The acidic phosphatase level decreased from 2.39 to $1.91 \mathrm{U} / \mathrm{L}$ for $E$. vermiculata while it increased from 2.19 to $2.33 \mathrm{U} / \mathrm{L}$ for $M$. obstructa. Kandil et al.[12] Observed that acetylsalicylic acid when combined with methomyl was more effective against both alkaline and acid phosphatase enzymes than each compound alone in the two snail species, $E$. vermiculata and M.obstructa.

\section{d. Cholesterol:}

The data in table (2) cleared the response of cholesterol for the investigated snails species to the previous tested compound. Results showed increasing of cholesterol level after 3 days of treatment with acetic acid from 222.3 to 374.6 for $E$. vermiculata meanwbile cholesterol decreased from 412.8 to $201.3 \mathrm{mg} / \mathrm{dL}$ for the M. obstructa Mobarak, [17]. Reported that acetylsalicylic had strong effect on ALP and ACP enzymes which are responsible to the mucus secretion of snail this effect lead to inhibit the production of the mucus and shell materials that is very important for snail life. 
Also, the acetylsalicylic acid affected on the total lipid and cholesterol which important for synthesis of shell. In the present investigation, scratch and abrasion was observed on some treated snails (Fig.,2-4).

It has been reported that lipid content increased when the animals encountered stressful conditions Nandurkar and Zambare [18].This may explain the increasing in cholesterol and total lipids observed in the present investigation after treatment .

Farkas et al. [8] recorded that increase in ALP enzymes could be due to a variety of conditions, including muscle damage, intestinal and hepatopancreatic injury, and toxic hepatitis.

\section{Field experiments:}

The field performance of the tested compounds against $E$. vermiculata and $M$. obstructa was shown in Table (3\&4). The results revealed that the acetic acid 20\% achieved the highest population reduction of snail $(63.72 \%)$ followed by acetic acid $16 \%$ (58.68\%), then Methomyl $(64.48 \%)$ for $E$. vermiculata snail. While in the case of $M$. obstructa the results indicated that, the
Methomyl achieved the highest population reduction of snail (91.313\%), followed by acetic acid $20 \%(72.45 \%)$ then acetic acid $16 \%$ (60.80\%), Comparing the data in Tables $(3 \& 4)$ it is cleared that under field conditions $M$. obstructa was more sensitive than $E$. vermiculata to methomyl which caused $91.313 \%$ population reduction on the first species comparatively with $65.21 \%$ in case of second species. Field results are in contradicted with those obtained by laboratory trails. In spite of acetic acid (16\& 20\%), were the superior in the laboratory, it had the lowest effect under field condition. This may be attributed to the weather factors and natural conditions (temperature, humidity, and light ....etc.). These factors may be affected on this compound inducing degradation or decomposition led to reduce its toxic action against snails. In comparison, Kandil et al. [12] reported that the combination of methomyl with acetylsalicylic acid achieved the highest population reduction percentage of both snails E. vermiculata and M. obstructa., followed by methomyl alone.

Table (1): Toxicity of acetic acid on adult of Eobania vermiculata and Monacha obstructa.

\begin{tabular}{|c|c|c|}
\hline \multirow{2}{*}{ Conc. (\%) } & Eobania vermiculata & Monacha obstructa \\
\cline { 2 - 3 } & Mortality \% after 72hr & Mortality \% after 72hr \\
\hline Control & 0.0 & 0.0 \\
\hline 2 & 0.0 & 40 \\
\hline 4 & 25 & 90 \\
\hline 6 & 35 & 92.5 \\
\hline 8 & 40 & 100 \\
\hline 10 & 50 & 100 \\
\hline 12 & 65 & - \\
\hline 14 & 75 & - \\
\hline Slope & $2.3880 \pm 0.2987$ & $2.5935 \pm 0.4573$ \\
\hline LC 50 & $8.6897 \%$ & $6.1949 \%$ \\
\hline LC $_{90}$ & $29.9007 \%$ & $6.8481 \%$ \\
\hline
\end{tabular}
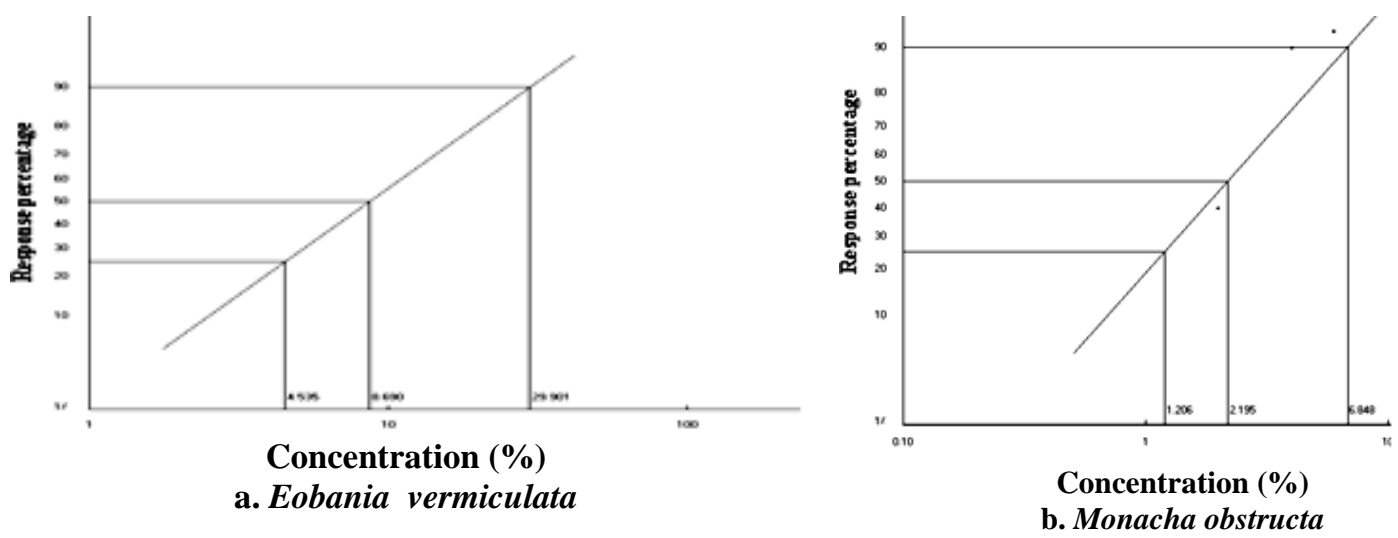

Fig (1,a\&b).Ldp lines of acetic acid on laboratory of $E$. vermiculata and M.obstructa. 
Table (2): Effect of $\mathrm{LC}_{50}$ of acetic acid on total protein, total lipid ,alkaline phosphatase acid phosphatase , cholesterol of E. vermiculata and M. obstructa terrestrial snails after three days.

\begin{tabular}{|c|c|c|c|c|c|c|}
\hline Snail species & Treatment & $\begin{array}{c}\text { Total } \\
\text { protein } \\
(\mathrm{g} / \mathrm{dl}) \\
\end{array}$ & $\begin{array}{l}\text { Total lipid } \\
\text { (g/dl) }\end{array}$ & $\begin{array}{c}\text { Alkaline } \\
\text { phosphatase } \\
\text { (U/L) }\end{array}$ & $\begin{array}{c}\text { Acid } \\
\text { phosphatase } \\
(\mathrm{U} / \mathrm{L})\end{array}$ & $\begin{array}{l}\text { Cholestero } \\
1(\mathrm{mg} / \mathrm{dl})\end{array}$ \\
\hline \multirow{4}{*}{$\begin{array}{c}\text { Eobania } \\
\text { vermiculata }\end{array}$} & Control & $\begin{array}{c}0.195 \pm \\
0.011\end{array}$ & $\begin{array}{l}4.96 \pm \\
0.05 \\
\end{array}$ & $\begin{array}{c}666.58 \pm \\
10.070 \\
\end{array}$ & $\begin{array}{l}2.39 \pm \\
0.131 \\
\end{array}$ & $\begin{array}{c}222.3 \pm \\
7.090 \\
\end{array}$ \\
\hline & $\begin{array}{c}\mathrm{LC}_{50} \text { of Acetic } \\
\text { acid }\end{array}$ & $1.99 \pm 0.02$ & $\begin{array}{l}2.78 \pm \\
0.061 \\
\end{array}$ & $\begin{array}{c}86.867 \pm \\
5.672 \\
\end{array}$ & $\begin{array}{c}1.91 \pm \\
0.0754 \\
\end{array}$ & $\begin{array}{l}374.6 \pm \\
14.674 \\
\end{array}$ \\
\hline & F Value & 18341.7 & 2299.55 & 7547.44 & 30.18 & 261.99 \\
\hline & LSD & 0.0368 & 0.1262 & 18.527 & 0.2426 & 26.124 \\
\hline \multirow{4}{*}{$\begin{array}{l}\text { Monacha } \\
\text { obstructa }\end{array}$} & Control & $\begin{array}{c}0.168 \pm \\
0.005 \\
\end{array}$ & $\begin{array}{l}2.89 \pm \\
0.061 \\
\end{array}$ & $\begin{array}{c}333.92 \pm \\
21.833 \\
\end{array}$ & $\begin{array}{c}2.19 \pm \\
0.03\end{array}$ & $\begin{array}{l}412.8 \pm \\
11.031 \\
\end{array}$ \\
\hline & $\begin{array}{c}\mathrm{LC}_{50} \text { of Acetic } \\
\text { acid }\end{array}$ & $\begin{array}{c}2.1 \pm \\
0.226\end{array}$ & $\begin{array}{l}3.22 \pm \\
0.267\end{array}$ & $\begin{array}{c}212.41 \pm \\
4.875\end{array}$ & $\begin{array}{l}2.33 \pm \\
0.078 \\
\end{array}$ & $\begin{array}{c}201.3 \pm \\
1.621 \\
\end{array}$ \\
\hline & F Value & 219.02 & 4.37 & 88.51 & 8.40 & 1079.48 \\
\hline & LSD & 0.363 & 0.438 & 35.86 & 0.134 & 17.87 \\
\hline
\end{tabular}

Table (3): Field performance of certain compound against Eobania vermiculata snail

\begin{tabular}{ccccc}
\hline Treatment & $\begin{array}{c}\text { Rate of } \\
\text { application }\end{array}$ & $\begin{array}{c}\text { No. of individual } \\
\text { before treatment }\end{array}$ & $\begin{array}{c}\text { No. of alive } \\
\text { individual after } \\
\text { treatment }\end{array}$ & $\begin{array}{c}\text { \% population } \\
\text { reduction }\end{array}$ \\
\hline Control & - & 112 & 98 & 12.5 \\
Acetic Acid & $16 \%$ & 130 & 47 & 58.68 \\
Acetic Acid & $20 \%$ & 63 & 20 & 63.72 \\
Methomyl (90\%) & $300^{\text {g/fdean }}$ & 74 & 23 & 64.48 \\
\hline
\end{tabular}

Table (4): Field performance of certain compound against Monacha obstructa snail

\begin{tabular}{ccccc}
\hline Treatment & $\begin{array}{c}\text { Rate of } \\
\text { application }\end{array}$ & $\begin{array}{c}\text { No. of individual before } \\
\text { treatment }\end{array}$ & $\begin{array}{c}\text { No. of alive } \\
\text { individual after } \\
\text { treatment }\end{array}$ & $\begin{array}{c}\text { \%population } \\
\text { reduction }\end{array}$ \\
\hline Control & - & 45 & 28 & 37.7 \\
Acetic Acid & $16 \%$ & 41 & 10 & 60.80 \\
Acetic Acid & $20 \%$ & 35 & 6 & 72.45 \\
Methomyl $(90 \%)$ & $300^{\mathrm{g}} /$ fdean & 37 & 2 & 91.313 \\
\hline
\end{tabular}

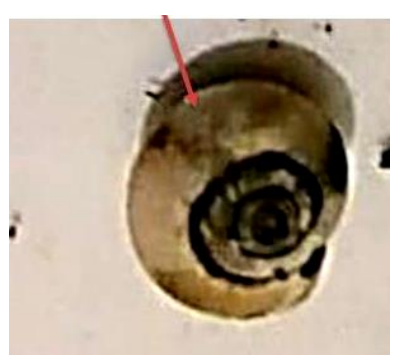

Fig. (2) scratch and abrasion of Monacha shell

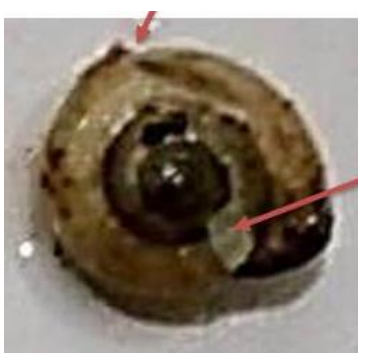

Fig.(3) scratch and abrasion of Monacha shell

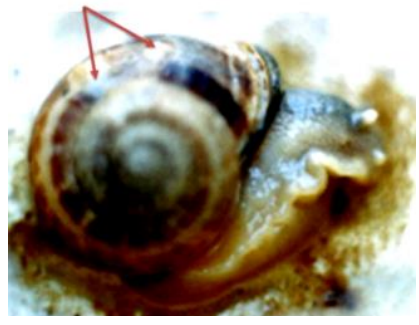

Fig.(4) scratch and abrasion of Eobania shell 


\section{REFERENCES}

[1] Abbott, W.S. (1925). A method of computing the effectiveness of an insecticide. J. Econ. Entomol., 18: 265-267.

[2] Ascher, R. S. and Mirian, F. (1981). The residual contact toxicity of Bay Sir 8514 to Spodopetera littoralis larvae. Phytoparasitica.; 9 (2): 133-137.

[3] Azzam, K. M. and Abd El-Hady, E. A. (2018). Survey on terrestrial molluses and parasitic nematodes as bio control agents in some Governorates. Menoufia J. plant.. Prot.,3 (2):45-52.

[4] Belfield A. and Goldberg D. M. (1971) Revised assay for serum phenyl phosphatase activity using 4-amino-antipyrine. Enzymes 12:561-573.

[5] Bergmeyer, H. (1963). Methods of enzymatic analysis. Academic press In New York, pp., 886.

[6] Ellefson, R. D. and Caraway, W. T. (1976). Fundamentals of clinical chemistry . Ed. Titez NW, P 506.

[7] Eshra, E. H. (2013). Survey and distribution of terrestrial snails in fruit orchards and ornamental plants at Alexandria and El-Behira Governorates, Egypt, Alex. Sci. Exchange J.; 34 (2): 242- 248.

[8] Farkas J, Farkas P, and Hyde D (2004). Liver and gastroenterology tests .In: Lee M 3rd (ed) Basic skills in interpreting laboratory data .American Society of Health-System Pharmacists, Bethesda, pp 330-336

[9] Henderson, C. and Tilton, W. F. (1952).Tests with acaricides against the brown wheat mite. J. Econ. Entomol., 18 (2): 157-161.

[10] Henry, R. J. (1964). Clinical Chemistry, Principles and Techniques. Harper and Row Publishers. New York P. 181.

[11] Iglesias, J., Castillejo J. and Castro R. (2003). The effects of repeated application of molluscicides metaldehede and the biocontrol nematode phasma rhabditis hermaphrodita on mollusks earth worms, nematodes, acarids and collembolans: a two year study in north-west spain. Pest manag. Sci., 59: (12) 17-24.

[12] Kandil, M. A.; El-Deeb, H. I.; Eweis, E. A.; Gabr, W. M. and Mobarak Soha, A. (2014).Is acetylsalicylic acid has ability to disturb the physiological role of mucus gland of land snail species? J. Agric. Res. 92 (1) :53-73.

[13] Khater, A. A.; El-Sheakh, A. A.; ElSheamy, M. K. and Hussein, M. Z. (1990). Biochemical effects of lannate and larvin on Tilapia nilotica fingerlings. Egypt. J. Appl. Sci., 5(8): 227-235.

[14] Khidr, E.k.(2015) Effect of some environmentally safety biopesticides on some land molluscs species in Qalubia and Sharkia Governorates. PhD. Ain Shams University.

[15] Kind, P. R. N. and King, E.J.(1954). Estimation of plasma phosphatase by determination of hydrolysed phenol with amino antipyrine. J. Clin. Path., 7: 322-326.

[16] Mobarak, S.A.(2008). Efficacy and toxicological studies for some binary mixtures of some pesticides with acetylsalicylic or tannic acids against the land snails Eobania vermiculata (Mulier) and Monacha obstructa (Mulier).PhD. Fac. Agric. Cairo Univ.,Egypt.

[17] Mobarak, S.A.(2014). Biochemical impacts of various compounds on two land snail species Eobania vermiculata and Monacha obstructa. Bull Fac. Agric. Cairo Univ. Egypt . 65(1):125-132. 19 ref.

[18] Nandurkar HP, Zambare SP (2012). Comparative study of acute and chronic exposure of chloramphenicol on total lipid contents in different tissues of model animals, Lamellidens corrianus (Lea) and Parreysia cylindrica (Annandale and Prashad). Int Multidiscip Res J 2(3):33-35.

[19] SAS Institute (1988). SAS/ STAT User s Guide, Ver. 6.03. SAS Institute Inc., Cary, North Carolina.

[20] Speiser, B. and Kistler, C. ( 2002). Field tests with a molluscicide containing iron phosphate. Crop Protection, 21: 389-94.

[21] Tietz N.W. (1994). Fundamentals of clinical chemistry 2nd edn. p 692 Bulinus truncatus. J Egypt Ger Soc Zool 24:17-35

[22] Youssef, A. S. (2001). Efficacy of certain pesticides against land snail Monacha contiana and Eobania vermiculata under Laboratory condition. J.Agric. Sci. Mansoura Univ., 26(2): 1161-1167.

[23] Zollner, N. and Kirsch, K. (1962). Determination of Lipids (micro method) by means of sulphophosphovanilin reaction 
common to many natural lipids (allknown plasma lipids) Z. Gas Exp. Med., 135: 545-561.
الملخص العربي :

لار اسة كفاءة حمض الخليك و الميثوميل على قوقع

الحدائق البنى E. vermiculata الزجاجى M. obstructa اجريت بعض التجارب

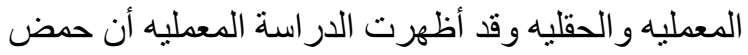
الخليك له تأثير معنوى أكثر على ق قوقع البرسيم الزجاجى M. obstructa من قوقع قوقع الحدائق البنى E. vermiculata بالنسبة لقوقع البرسيم الزجاجى M. obstructa و

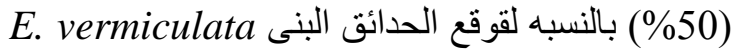
عند تركيز10\% بعد 72 ساعه من المعامله بالمقارنه

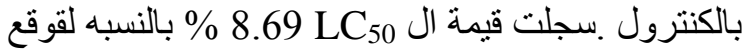
E. vermiculata الزجاجى M. obstructa بعد 72 ساعه من المعامله

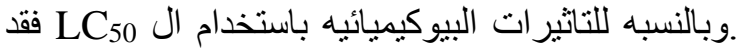
كانت هنالك زياده فى مستوى البروتين الكلى بالنسبه

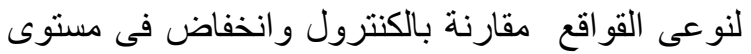
الدهون الكليه من 4,96 الى 2,78 g/dl بالنسبه لقوقع

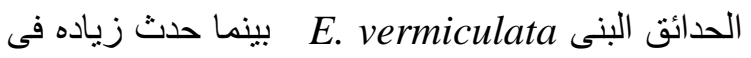

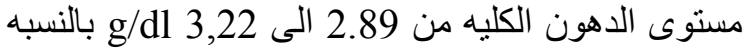

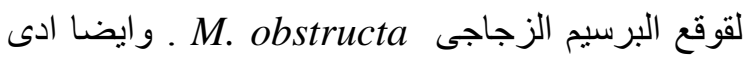
استخدام قيمة ال LC50 انخفاض فى مستوى الفوسفاتيز القاعدى و الحامضى لكلا نو عي القو اقع ولكن حدث زياده

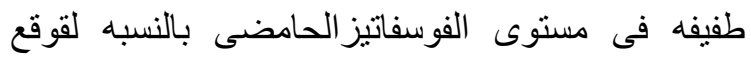
البرسيم الزجاجى M. obstructa . و واوضحت النتائج ان حامض الخليك سبب انخفاض فى مستوى

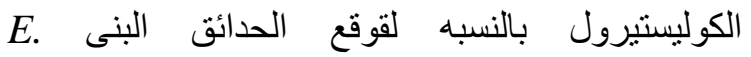
vermiculata الزجاجى M. obstructa, اما تأثيره ضد نوعى القو القو اقع السابق ذكرهم تحت الظروف الحقليه فقد كان قوقع تأيره البرسيم الزجاجى M. obstructa اكثر حساسيه من E. vermiculata قوقع الحدائق البنى 